\title{
The main findings in histopathological examination of human corneal buttons with lymphangiogenesis
}

\author{
Principais achados do exame histopatológico de botões \\ corneanos humanos com linfangiogênese
}

Karine Feitosa Ximenes ${ }^{1}$, Jailton Vieira Silva², Karla Feitosa Ximenes Vasconcelos ${ }^{3}$, Fernando Queiroz Monte ${ }^{4}$

\begin{abstract}
Objective: To detect the presence of lymphatic vessels in the cornea through histopathological examination, trying to identify findings that are most commonly found with the presence of these vessels in this tissue. Methods: Retrospective descriptive study of human corneal buttons with lymphangiogenesis. Tissues were obtained from penetrating keratoplasty in the period between the years 2006 and 2013. A medical record review was conducted looking for information about sex, age and graft etiology. Results: 89 corneal buttons were included, out of which 37 were from female patients and 52 were from male patients. The average age was $47.70 \pm 23.95$ years $($ mean $\pm S D)$. Lymphangiogenesis was found mainly associated with hemangiogenesis. However, isolated lymphangiogenesis was observed in $28(31.46 \%)$ patients. In $18(20.22 \%)$ cases were found an amount of lymphatic vessels approximately four times higher than that found in most part of the sample. A lot of cases were found in inflammatory conditions such as infection and perforation. Near the lymphangiogenesis, we found many cases of anterior synechia and myofibroblasts. In 17 (16.35\%) cases, no change was observed in the vicinity of corneal lymphatic vessels. Conclusion: We demonstrated through a histopathological examination, that findings admittedly associated with lymphangiogenesis like inflamamatory processes, are also frequently found in cases of human corneas that have lymphatic vessels. However, other findings such as lymphangiogenesis without the presence of angiogenesis, the presence of a greater amount of vessels in some cases and lymphangiogenesis without changes in its proximity remain in need of a better understanding.
\end{abstract}

Keywords: Lymphangiogenesis; Angiogenesis; Cornea/pathology; keratoplasty

\section{RESUMO}

Objetivo: Detectar a presença de vasos linfáticos na córnea através do exame histopatológico, buscando identificar os achados que são encontrados com maior frequência junto à presença desses vasos nesse tecido. Métodos: Estudo retrospectivo descritivo de botões corneanos humanos com linfangiogênese. Os tecidos foram provenientes de ceratoplastia penetrante no período compreendido entre os anos de 2006 e 2013. Foi realizada revisão de prontuários em busca de informações sobre sexo, idade e etiologia do transplante. Resultados: Foram incluídos 89 botões corneanos, sendo 37 de pacientes do sexo feminino e 52 do sexo masculino. A média das idades foi de 47,70 $\pm 23,95$ anos (média \pm DP). Linfangiogênese foi encontrada principalmente associada à hemangiogênese. Linfangiogênese isolada, no entanto, foi observada em 28 (31,46\%) casos. Em 18 (20,22\%) casos foram encontrados uma quantidade de vasos linfáticos cerca de quatro vezes maior que aquela encontrada na maioria das amostras. Em um grande número de casos foram encontrados condições inflamatórias como infecção e perfuração. Nas proximidades da linfangiogênese, encontramos muitos casos de sinéquia anterior e miofibroblastos. Em $17(16,35 \%)$ casos nenhuma alteração foi evidenciada nas proximidades dos vasos linfáticos corneanos. Conclusão: Demonstramos, através do exame histopatológico, que achados reconhecidamente associados à linfangiogênese, como os processos inflamatórios, são encontrados também com frequência em casos de córneas humanas que possuem vasos linfáticos. Porém, outros achados evidenciados, como a linfangiogênese desacompanhada de angiogênese, a presença de uma maior quantidade de vasos em alguns casos e a linfangiogênese sem alterações em sua proximidade, permanecem necessitando de uma melhor compreensão.

Descritores: Linfangiogênese; Angiogênese; Córnea/patologia; Ceratoplastia

${ }^{1}$ Ocular Pathology Unit of the Ceará State Eye Bank, Fortaleza/CE, Brazil.

${ }^{2}$ Department of Ophthalmology, Federal University of Ceará, Fortaleza/CE, Brazil.

${ }^{3}$ Preceptor at the Ophthalmology Residency Programme, General Hospital of Fortaleza, Fortaleza/CE, Brazil.

${ }^{4}$ Ceará State Eye Bank, Fortaleza/CE, Brazil.

Work conducted at the Ceará State Eye Bank, Fortaleza/CE, Brazil.

The authors declare no conflict of interest

Received for publication: 23/9/2014 - Accepted for publication: 5/1/2015

Rev Bras Oftalmol. 2015; 74 (1): 24-9 


\section{INTRODUCTION}

$\mathbf{T}$ he lymphatic system was first described in the seventeenth century $^{(1)}$. In contrast with blood vessels, which have been extensively studied in the past, lymphatic vessels were disregarded for centuries ${ }^{(2)}$. Hence, lymphangiogenesis has been traditionally overshadowed by the emphasis given to the blood circulatory system. This is due in part to the failure to identify lymphangiogenic factors ${ }^{(3)}$ and marker proteins expressed exclusively by lymphatic endothelial cells, which enable their differentiation from blood endothelial cells ${ }^{(3,4)}$.

This scenario has been rapidly changing since the identification of the first lymphangiogenic factor: vascular endothelial growth factor C (VEGF-C $)^{(3,5)}$. The second major breakthrough in the field of lymphangiogenesis was the discovery of specific markers of the lymphatic endothelium ${ }^{(3)}$. Examples of these markers include: podoplanin, a membrane glycoprotein of glomerular podocytes ${ }^{(6)}$; the transcription factor Prox1, involved in the differentiation of endothelial cells into the lymphatic phenotype $^{(7,8)}$; and LYVE-1, a lymphatic endothelium-specific hyaluronan receptor ${ }^{(9)}$.

Due to its accessible location and unique tissue heterogeneity, the eye is an excellent site for studying lymphatic vessels. A wide range of ocular disorders have been identified, whether as local conditions or manifestations of systemic diseases $^{(2)}$. It has been suggested that lymphatic vessels or lymphangiogenesis may be involved in the pathogenesis of glaucoma, ocular tumours, and conditions related to corneal grafting. Lymphatic vessels or lymphangiogenesis may also play an important role in the pathology of uveitis, choroidal neovascularisation, and macular oedema, due to the role of lymphatic vessels in inflammation and tissue oedema. Lymphangiogenesis may therefore be a therapeutic target for some ocular disorders ${ }^{(10)}$.

Considering the above, our aim was to detect the presence of lymphatic vessels in the cornea through histopathological examination, seeking to identify the most frequent findings associated with corneal lymphatics. Recognising that some conditions are more or less frequently associated with lymphatic vessels in the cornea may lead to a better understanding of ocular lymphangiogenesis and provide information on which cases could benefit from potential anti-lymphangiogenic therapies, helping to reduce ocular morbidity.

\section{MethodS}

After obtaining approval from the Research Ethics Committee of the General Hospital of Fortaleza, we examined corneal buttons from penetrating keratoplasties conducted between 2006 and 2013 and submitted to the Ceará State Eye Bank for histopathological examination.

Tissues were sent to the Anatomical Pathology unit, where they were fixed in $10 \%$ neutral formaldehyde and sliced.

The specimens were embedded in paraffin, cut into 2- to 5 - $\mu \mathrm{m}$ thick slices, and stained with haematoxylin-eosin. Following preparation, tissues were examined by the authors with an optical microscope.

As we had no special means for detecting lymphatic vessels and used routine staining, it was necessary to select which cases would be included in the study. Therefore, we selected only samples

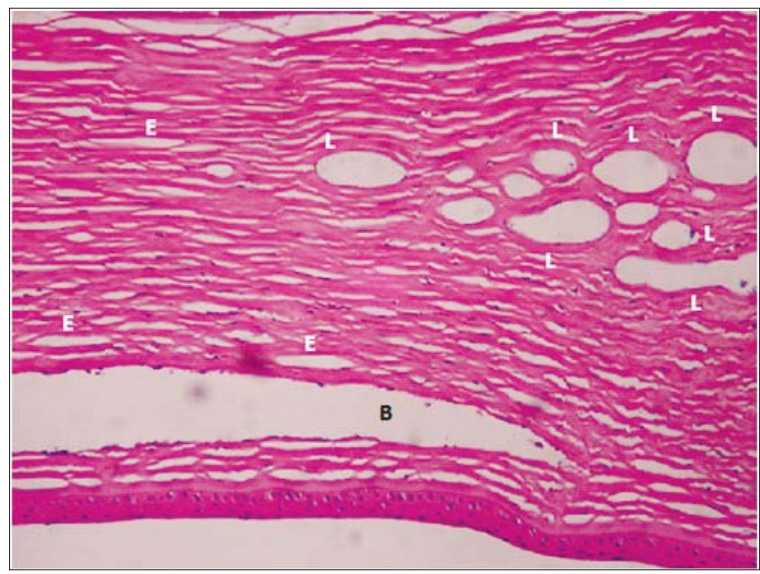

Figure 1: Presence of lymphatic vessels in a case of corneal oedema (L) indicates some of the lymphatic vessels considered in the study. (E) indicates the empty spaces found between keratocytes and corneal collagen fibres due to the accumulation of oedematous fluid, highlighting the difference between these spaces and lymphatic vessels. (B) indicates a large stromal bubble.

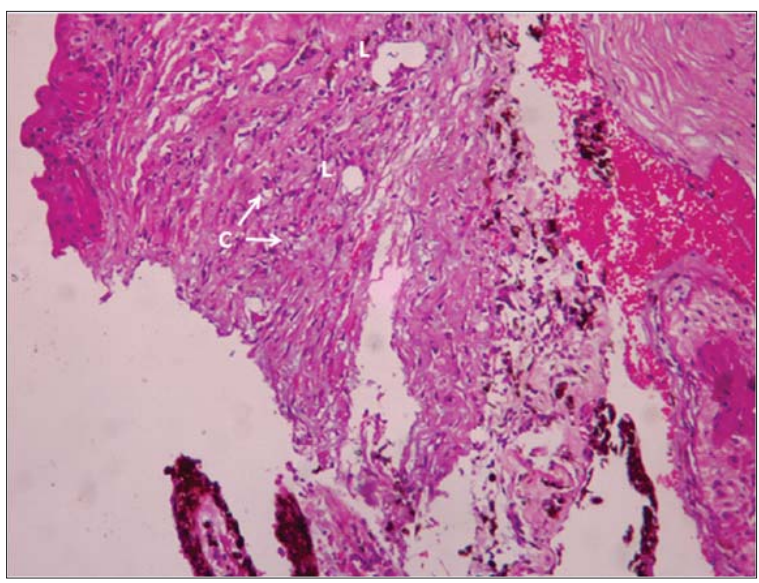

Figure 2: Presence of lymphatic vessels (L) in corneal tissue with anterior synechia. Arrows at (C) indicate empty spaces that can be considered as capillaries

in which lymphatic vessels could be unmistakably identified, i.e. specimens where endothelial cells could be clearly seen, with no leukocytes or erythrocytes being observed inside these vessels (Figures 1 and 2). Due to the greater difficulty in identifying the endothelium in capillaries, these were not included (Figure 2). Lymphatic vessels that for some reason had sharper edges were also excluded from the study, due to the possibility of mistaking them for empty spaces found between keratocytes and stromal collagen fibres in cases of corneal oedema (Figure 1).

This was a retrospective, descriptive study of the histopathological findings in human corneal buttons presenting lymphangiogenesis. Due to its descriptive nature, we only assessed how often these findings appeared. Another reason for using this type of statistics was the rigor with which cases were selected and included - because the staining method was not specific for detecting lymphatic vessels, we believe the number of lymphatics might have been underestimated. In further studies, 


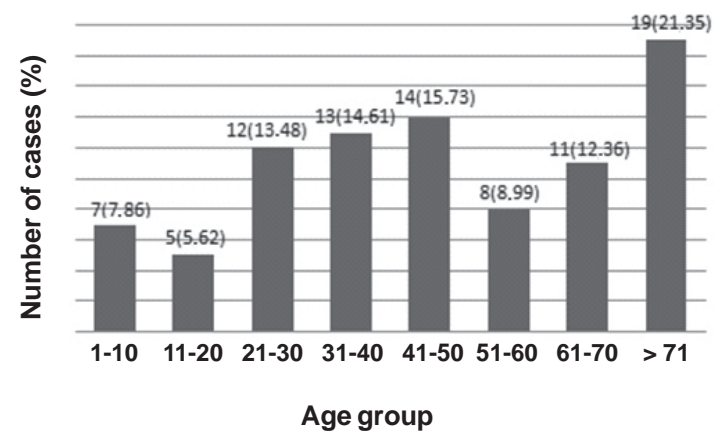

Chart 1: Distribution of cases by age group (in years)

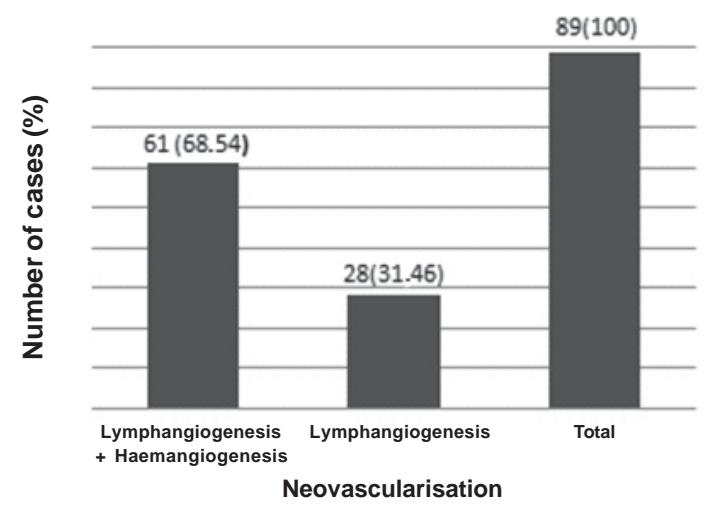

Chart 2: Distribution of cases according to the presence of neovascularisation

using specific means for detecting lymphatic vessels, statistical probabilities can also be calculated.

After selecting the cases with corneal lymphangiogenesis we followed a protocol to obtain additional information by examining slides and reviewing medical records. In examining slides we searched for the presence of lymphangiogenesis and/ or haemangiogenesis, counted the number of lymphatic vessels per slide, determined whether these vessels were clustered together or were near any corneal changes, and looked for other findings. In the medical record review we extracted information on gender, age, and the indication for transplantation.

\section{Results}

Eighty-nine corneal buttons were included in the study, of which 37 were from female patients and 52 from male patients. Age ranged from 1 to 89 years, with a mean age of $47.70 \pm 23.95$ years (mean $\pm \mathrm{SD})$. A detailed distribution of cases by age is presented in Chart 1, which shows a large number of cases (30 cases, $33.71 \%$ ) in the age group above 61 years.

Chart 2 shows the distribution of cases according to the presence of neovascularisation.

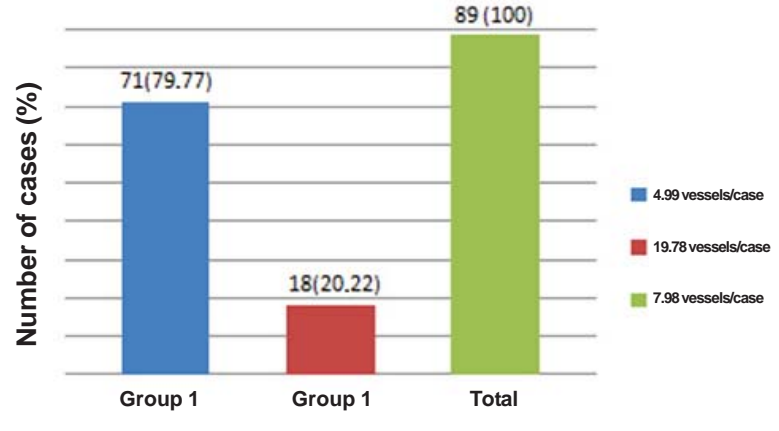

Chart 3: Mean number of lymphatic vessels per case

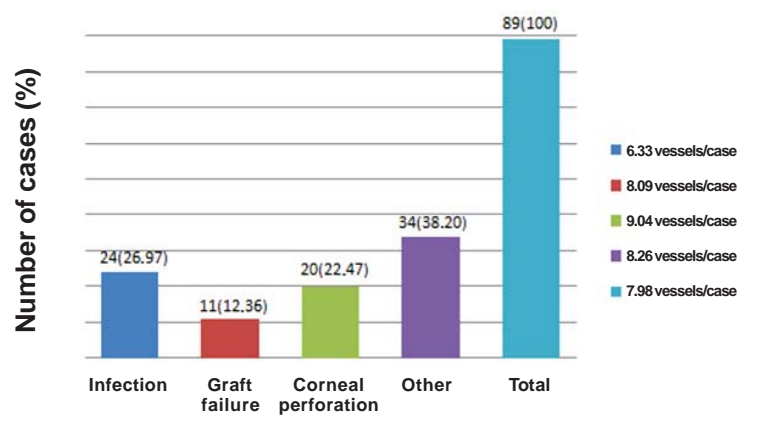

Chart 4: Corneal diseases and mean number of lymphatic vessels per case

Most cases (68.54\%) presented lymphangiogenesis associated with haemangiogenesis.

However, $28(31.46 \%)$ cases presented lymphangiogenesis alone.

The mean number of lymphatic vessels found per case is presented in Chart 3, which shows that most cases $(79.77 \%)$ had a relatively low number of vessels (4.99 vessels). However, 18 cases $(20.22 \%)$ presented a high mean number of vessels $(19.78$ vessels), approximately fourfold greater than the mean for most of the sample (4.99 vessels) and also well above the mean for the overall sample ( 7.98 vessels).

The corneal diseases found in the studied cases are presented in Chart 4. Inflammatory conditions (Figure 3) such as infections and corneal perforation (Figure 4) were present in a large number of cases (44 cases, $49.44 \%$ ). The highest mean number of vessels per case was found in samples with corneal perforation (9.04 vessels).

As regards changes found near corneal lymphatic vessels, myofibroblasts (Figure 5) and anterior synechiae (Figure 2) were observed near lymphangiogenesis in a large number of cases (38 cases, $36.53 \%$ ), as shown in Chart 5 . In 17 cases $(16.35 \%)$ no particular changes were observed near lymphatic vessels. 


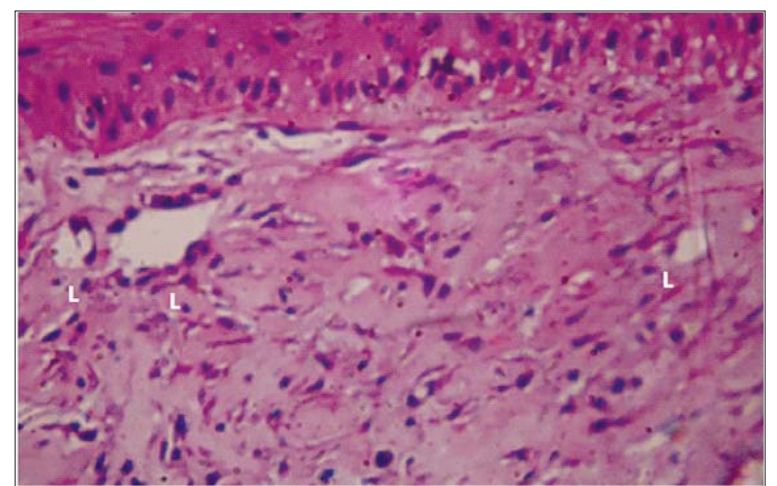

Figure 3. Lymphatic vessels (L) in a corneal inflammatory process

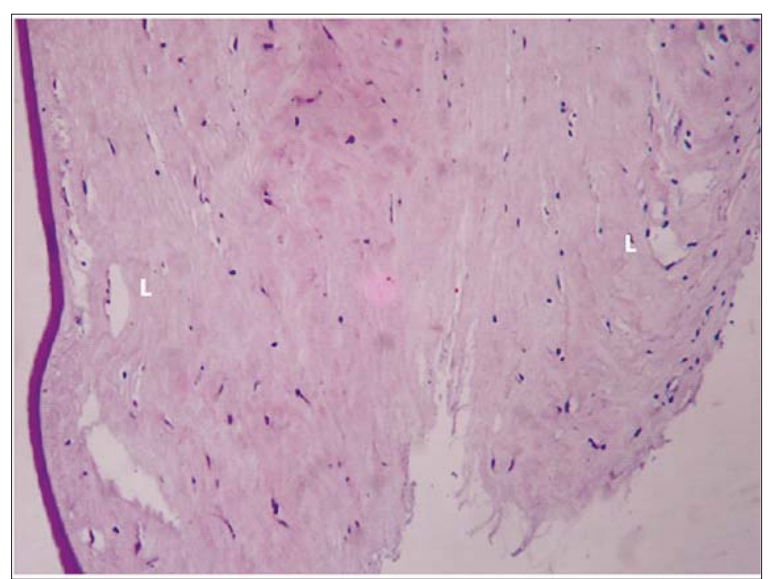

Figure 4. Lymphatic vessels (L) in a case of corneal perforation

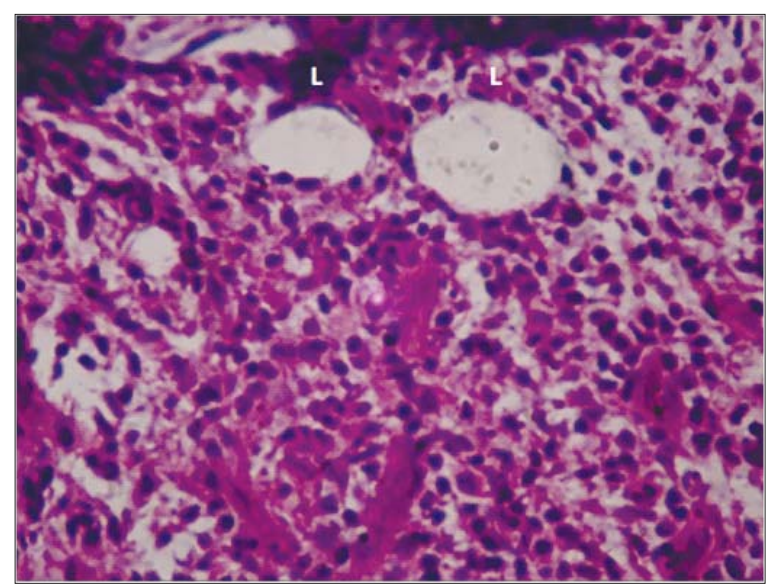

Figure 5. Lymphatic vessels (L) near myofibroblasts replacing Bowman's membrane in the cornea

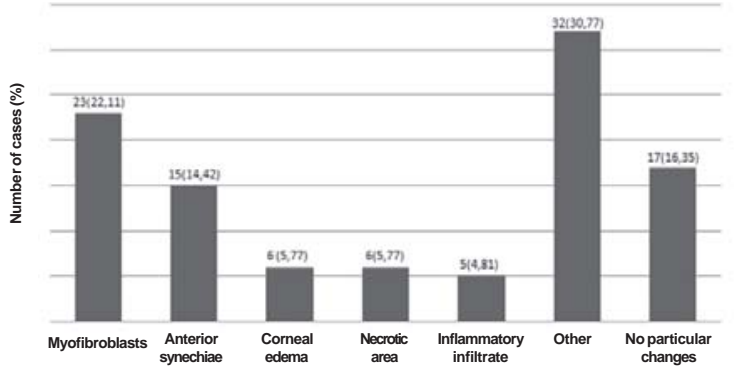

Chart 5. Corneal changes found near lymphatic vessels

\section{Discussion}

The lymphatic network runs parallel to the blood circulatory system, penetrating into most body tissues and playing an important role in several body functions, which include but are not limited to: immune responses ${ }^{(2,10,11,12)}$, cancer metastasis ${ }^{(2,3)}$, vitamin and fat absorption ${ }^{(2,11)}$, and maintaining fluid balance in tissues ${ }^{(2,10,11,12)}$. The lymphatic system has therefore two major functions: draining excess extracellular fluid from capillary beds back into the bloodstream, and capturing antigens for presentation to the immune system in the lymphoid compartment (e.g., lymph nodes $)^{(12)}$. Lymphatic vessel disorders can be associated with several diseases, such as inflammatory conditions ${ }^{(2,10,11,13)}$, cancer metastasis $(2,3,10,11,13)$, lymphoedema ${ }^{(2,10,13)}$, transplant rejection $^{(2,13,14)}$ diabetes $^{(2)}$, immune diseases ${ }^{(2,13)}$ and delayed wound healing ${ }^{(13)}$.

Lymphatic vessels were believed not to exist in the eye, except in the conjunctiva, until lymphatic endothelial markers and lymphangiogenic factors were identified ${ }^{(10)}$.

Recent studies, however, have shown that the ciliary body ${ }^{(15)}$, lacrimal gland, orbital meninges, and extraocular muscles $^{(16)}$ contain lymphatic vessels and that the choroid has a lymphatic-like system ${ }^{(10)}$. There have been reports of an antigen drainage pathway through conjunctival lymphatic vessels from the anterior chamber or the vitreous ${ }^{(17,18)}$. A large population of non-endothelial LYVE-1+ cells derived from the bone marrow have also been observed in most ocular tissues, and a subpopulation of such cells may represent resident precursor cells necessary for the formation of new ocular or orbital lymphatic vessels $^{(19)}$. In contrast with most body tissues, which normally contain lymphatic vessels, ocular tissues have a heterogeneous nature: while the conjunctiva is rich in lymphatics, they are absent in the cornea and retina. However, the cornea may also undergo lymphangiogenesis under inflammatory conditions ${ }^{(2)}$.

The normal cornea is devoid of lymphatic and blood vessels $^{(2,12,20)}$, but it may undergo secondary vascularisation due to a variety of corneal diseases ${ }^{(2,20)}$ as well as surgical manipulation ${ }^{(20)}$.

As with other organs, while abnormal corneal blood vessel growth has been investigated for several years, studying corneal lymphatics was difficult until the recent discovery of specific lymphatic markers ${ }^{(12)}$

Nonetheless, the cornea is now the best-studied and most well-characterised ocular tissue in lymphatic and blood vessel $\operatorname{research}^{(2,20)}$. From a wider perspective, the cornea is ideal for lymphatic research because it is accessible, transparent, and free 
of lymphatic vessels, though lymphatic growth can be induced.

Results from corneal studies are likely to improve our understanding of other conditions associated with lymphatic vessels $^{(2)}$.

Thus, we conducted a retrospective, descriptive study of corneal buttons from penetrating keratoplasties that contained lymphatic vessels, of which a large number of cases $(33.71 \%)$ involved subjects older than 61 years, as shown in Chart 1. As far as we know, there are no reports in the literature on the association between corneal lymphatic vessels and advanced age.

However, bullous keratopathy is also frequently found in in this age group ${ }^{(21-23)}$. Therefore, it is possible that our sample might have included a large number of cases of bullous keratopathy with corneal lymphangiogenesis, and the presence of lymphatics in oedematous tissues might represent an attempt to make fluids more transparent, as these vessels are known to be involved in maintaining fluid balance in tissues.

In most studied cases lymphangiogenesis was associated with haemangiogenesis (68.54\%), as shown in Chart 2.

However, lymphatic vessels without blood vessels were found in 28 cases $(31.46 \%)$. Many studies in the literature cite lymphangiogenesis and haemangiogenesis as related processes ${ }^{24-}$ ${ }^{27)}$, as was observed in most cases in our sample.

There have also been reports of growth factors involved in both haemangiogenesis and lymphangiogenesis, although some factors bind preferentially to lymphatic receptors while others to the endothelium of blood vessels ${ }^{(28)}$. Nagy et al. reported that vascular endothelial growth factor A (VEGF-A) triggers a strong lymphangiogenic response, in addition to inducing haemangiogenesis ${ }^{(29)}$. Shin et al. describe the important role of fibroblast growth factors (FGFs) in haemangiogenesis and the importance of FGF signalling through FGF receptor 3 (FGFR-3) in the early development of the lymphatic vascular system. Fibroblast growth factors 1 and 2 (FGF-1 and FGF-2) have also been shown to promote proliferation, migration and survival of endothelial lymphatic cells cultured without FGFR$3^{(8)}$. These results have led to the assumption that haemangiogenesis would be pre-requisite for lymphangiogenesis. A few studies, however, mention the possibility of lymphangiogenesis occurring without haemangiogenesis, as observed in a minority of cases $(31.46 \%)$ in our sample. Using rat corneas, Nakao et al. induced the physiological expression of lymphatics without blood vessels, indicating that lymphangiogenesis and haemangiogenesis may occur independently, despite being intrinsically related ${ }^{(30)}$. Using the corneal micropocket assay, Chang et al. demonstrated that a low dosage of FGF-2 induces selective lymphangiogenesis, providing further evidence that lymphatic growth is possible without haemangiogenesis in rat corneas ${ }^{(31)}$.

As regards the number of lymphatic vessels per case, most specimens $(79.77 \%)$ presented a mean number of 4.99 vessels, as shown in Chart 3. However, a group of 18 cases presented a mean of 19.78 vessels per specimen - a high number in comparison with both the majority of specimens (4.99 vessels) and the overall sample (7.98 vessels). Such a high number of lymphatic vessels is usually found in lymphangioma, which is characterised by dilated lymphatic vessels containing lymph and appears as a cyst-like multilocular lesion. Histological examination reveals proliferation and lymphatic ectasia with a network of empty channels lined by a flattened endothelium ${ }^{(32)}$. However, a more detailed study of these cases would be necessary to confirm the presence of corneal lymphangiomas in our sample.
Most corneal diseases (49.44\%) found in our sample were inflammatory conditions such as infections and corneal perforation, as shown in Chart 4. Other studies in the literature found similar results, reporting the induction of corneal lymphatic proliferation by toxic, inflammatory, infectious, traumatic, and chemical injury ${ }^{(2)}$. Reliable methods for studying corneal lymphangiogenesis using inflammation induced by sutures ${ }^{(27)}$ or alkali burns ${ }^{(33)}$ have also been described. A study that induced corneal neovascularization in rats using sutures showed an initial growth of both blood and lymphatic vessels following a temporary inflammatory insult to the cornea, although lymphatics regressed earlier than blood vessels ${ }^{(27)}$. Ecoiffier et al. also used sutureinduced inflammation to demonstrate different lymphangiogenic and haemangiogenic responses to an inflammatory stimulus, correlating these findings with others that show different regression periods ${ }^{(34)}$.

As regards changes found near lymphatic vessels (Chart 5), myofibroblasts and anterior synechiae were present in a large number of specimens, having been observed in 23 $(22.11 \%)$ and 15 cases $(14.42 \%)$, respectively. Considering that anterior synechiae are potential sequelae of inflammatory processes, their presence could also indicate an association between corneal lymphangiogenesis and adjacent inflammation. Although inflammation itself known to induce lymphatic growth, it was not frequently observed in the proximity of lymphatic vessels, with inflammatory infiltrates being found near lymphatic vessels in only five cases $(4.81 \%)$. The presence of myofibroblasts could represent lymphangiogenesis during wound healing, as described by Pepper(3). As previously mentioned, Shin et al. also highlight the role of FGFs in the development of the lymphatic system ${ }^{(8)}$.

Finally, Chart 5 shows that in 17 cases $(16.35 \%)$ no changes were found near corneal lymphatic vessels, suggesting that our understanding of lymphangiogenesis in corneal tissue remains incomplete.

\section{Conclusion}

This study used histopathological examination to demonstrate that inflammation and wound healing, which are known to be associated with lymphangiogenesis, are frequently found in human corneal specimens presenting lymphatic vessels. Other findings, however, such as the occurrence of lymphangiogenesis without haemangiogenesis, the large number of vessels found in some cases, and the presence of corneal lymphangiogenesis with no associated changes, still require further clarification, indicating that there is still much to be understood about this subject.

\section{REFERENCES}

1. Aselli G. De lacteibus sive lacteis venis, quarto vasorum mesaraicorum genere, novo invento. Milano: Mediolani; 1627.

2. Chen L. Ocular lymphatics: state-of-the-art Review. Limphology. 2009;42(2):66-76.

3. Pepper MS. Lymphangiogenesis and tumor metastasis: mith or reality? Clin Cancer Res. 2001;7(3):462-8.

4. Kerjaschki D. The crucial role of macrophages in lymphangiogenesis. J Clin Invest. 2005;115(9):2316-9.

5. Jeltsch M, Kaipainen A, Joukov V, Meng X, Lakso M, Rauvala H, et al. Hyperplasia of lymphatic vessels in VEGF-C transgenic mice. Science. 1997;276(5317):1423-25. 
6. Breiteneder-Geleff S, Soleiman A, Kowalski H, Horvat R, Amann G, Kriehuber E, et al. Angiosarcomas express mixed endothelial phenotypes of blood and lymphatic capillaries: podoplanin as a specific marker for lymphatic endothelium.Am J Pathol. 1999;154(2):385-94.

7. Wigle JT, Harvey N, Detmar M, Lagutina I, Grosveld G, Gunn MD, et al. An essential role for Prox1 in the induction of the lymphatic endothelial cell phenotype. EMBO J. 2002;21(7):1505-13.

8. Shin JW, Min M, Larrieu-Lahargue F, Canron X, Kunstfeld R, Nguyen $\mathrm{L}$, et al. Prox1 promotes lineage-specific expression of fibroblast growth factor (FGF) receptor-3 in lymphatic endothelium: a role for FGF signaling in lymphangiogenesis. Mol Biol Cell. 2006;17(2):576-84.

9. Banerji S, Ni J, Wang SX, Clasper S, Su J,Tammi R, et al. LYVE-1, a new homologue of the CD44 glycoprotein, is a lymph-specific receptor for hyaluronan. J Cell Biol. 1999;144(4):789-801.

10. Nakao S, Hafezi-Moghadam A, Ishibashi T. Lymphatics and lymaphangiogenesis in the eye. J Ophthalmol. 2012;2012:783163.

11. Karpanen T, Alitalo K. Molecular biology and pathology of lymphangiogenesis. Annu Rev Pathol. 2008;3:367-97.

12. Patel SP, Dana R. Corneal lymphangiogenesis: implications in immunity. Semin Ophthalmol. 2009;24(3):135-8.

13. Zhang H, Hu X, Tse J, Tilahun F, Qiu M, Chen L. Spontaneous lymphatic vessel formation and regression in the murine cornea. Invest Ophthalmol Vis Sci. 2011;52(1):334-8.

14. Dietrich T, Bock F, Yuen D, Hos D, Bachmann BO, Zah G, et al. Cutting edge: lymphatic vessels, not blood vessels, primarily mediate immune rejections after transplantation. J Immunol. 2010;184(2):535-9.

15. YücelYH, Johnston MG,Ly T, Patel M, Drake B, Gümus E, et al. Identification of lymphatics in the ciliary body of the human eye: a novel "uveolymphatic" outflow pathway. Exp Eye Res. 2009;89(5):810-9.

16. Sherman DD, Gonnering RS, Wallow IH, Lemke BN, Doos WG, Dortzbach RK, et al. Identification of orbital lymphatics: enzyme histochemical light microscopic and electron microscopic studies. Ophthal Plast Reconstr Surg. 1993:9(3):153-69.

17. Camelo S, Kezic J, Shanley A, Rigby P,McMenamin PG. Antigen from the anterior chamber of the eye travels in a soluble form to secondary lymphoid organs via lymphatic and vascular routes. Invest Ophthalmol Vis Sci. 2006;47(3):1039-46.

18. Camelo S, Lajavardi L, Bochot A, Goldenberg B, Naud MC, Fattal E, et al. Drainage of fluorescent liposomes from the vitreous to cervical lymph nodes via conjunctival lymphatics. Ophthalmic Res. 2008;40(34):145-50.

19. Xu H, Chen M, Reid DM,Forrester JV.LYVE-1-positive macrophages are present in normal murine eyes. Invest Ophthalmol Vis Sci. 2007;48(5):2162-71.

20. Cursiefen C, Chen L, Dana MR, Streilein JW. Corneal lymphangiogenesis: evidence, mechanisms, and implications for corneal transplant immunology. Cornea. 2003;22(3):273-81.

21. Araújo AA, Melo GB, Silva RL, Araújo Neta VM.[Epidemiological profile of the patients on the waiting list for cornea transplantation in the State of Sergipe, Brasil]. Arq. Bras. Oftalmol. 2004;67(4):613-6. Portuguese.

22. Almeida Sobrinho EF, Negrão BC, Almeida HG.[Epidemiological profile of patients waiting for penetrating keratoplasty in state of Pará, Brazil]. Rev Bras Oftalmol. 2011;70(6):384-90. Portuguese.

23. Santhiago MR, Monica LA, Kara-Junior N, Gomes BA, Bertino PM, Mazurek MGG, et al. [Profile of patient with aphakic/pseudopfakic bullous keratopaty attended at public hospital]. Rev Bras Oftalmol.2009;68(4):201-5. Portuguese.

24. Ling SQ, Liu C, Li WH, HU JG, Kuang WH. Corneal lymphangiogenesis correlates closely with hemangiogenesis after keratoplasty. Int J Ophthalmol. 2010;3(1):76-79.
25. Cursiefen C, Cao J, Chen L, Liu Y, Maruyama K, Jackson D, et al. Inhibition of hemangiogenesis and lymphangiogenesis after normalrisk corneal transplantation by neutralizing VEGF promotes graft survival. Invest Ophthalmol Vis Sci. 2004;45(8):2666-73.

26. Regina M, Zimmerman R, Malik G, Gausas R. Lymphangiogenesis concurrent with haemangiogenesis in the human cornea. Clin Experiment Ophthalmol. 2007;35(6):541-4.

27. Cursiefen C, Maruyama K, Jackson DG, Streilen JW, Kruse FE.Time course of angiogenesis and lymphangiogenesis after brief corneal inflammation. Cornea. 2006;25(4):443-7.

28. Kriehuber E, Breiteneder-Geleff S, Groeger M, Soleiman A, Schoppmann SF, Stingl G, et al. Isolation and characterization of dermal lymphatic and blood endothelial cells reveal stable and functionally specialized cell lineages. J Exp Med. 2001;194(6):797-808.

29. Nagy JA, Vasile E, Feng D, Sundberg C, Brown LF, Detmar MJ, et al. Vascular permeability factor/ vascular endothelial growth factor induces lymphangiogenesis as well as angiogenesis. J Exp Med. 2002;196(11):1497-506

30. Nakao S, Maruyama K, Zandi S, Melhorn MI, Taher M, Noda K, et al. Lymphangiogenesis and angiogenesis: concurrence and/or dependence? Studies in inbred mouse strains. FASEB J. 2010;24(2):504-13.

31. Chang LK, Garcia-Cardena G,Farnebo F,Fannon M,Chen EJ,Butterfield $\mathrm{C}$, et al. Dose-dependent response of FGF-2 for lymphangiogenesis. Proc Natl Acad Sci USA. 2004;101(32):11658-663.

32. Seca M,Borges P, Reimão P, Gomes M, Meireles A. Conjunctival Lymphangioma:A Case Report and Brief Review of the Literature. Case Rep Ophthalmol Med. 2012; 2012:836573.

33. Ling S, Lin H, Liang L, Xu J, Xu C, Zhao W, et al. Development of new lymphatic vessels in alkali-burned corneas. Acta Ophthalmol. 2009;87(3):315-22.

34. Ecoiffier T, Yuen D, Chen L. Differential distribution of blood and lymphatic vessels in the murine cornea. Invest Ophthalmol Vis Sci. 2010;51(5):2436-40.

\section{Corresponding author:}

Karine Feitosa Ximenes

Rua Andrade Furtado, 150, apto 1501, Bairro Cocó

Fortaleza/CE, Brazil

CEP: 60192-070

Email: karinefx@gmail.com

Tel: +55 8532626781 ; +55 8596733132

\section{Errata}

In the scientific article "The main findings in histopathological examination of human corneal buttons with lymphangiogenesis", the authors: Karine Feitosa Ximenes, Jailton Vieira Silva, Karla Feitosa Ximenes Vasconcelos and Fernando Queiroz Monte, published in the Journal of Ophthalmology in January-February 2015 edition (Rev Bras Oftalmol 2015; 74 (1): . 24-9) on page 27 there was a reversal in the order of figures 3 and 5 , subtitles are in the correct order . 


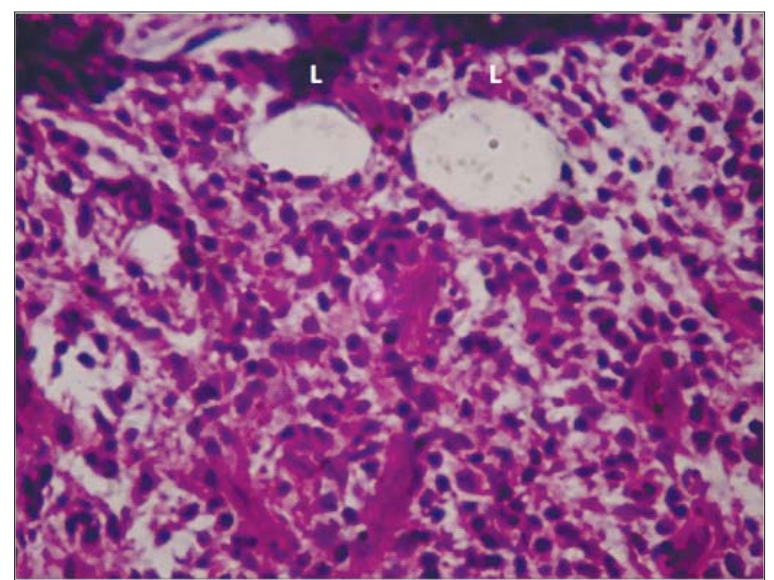

Figure 3. Lymphatic vessels (L) in a corneal inflammatory process

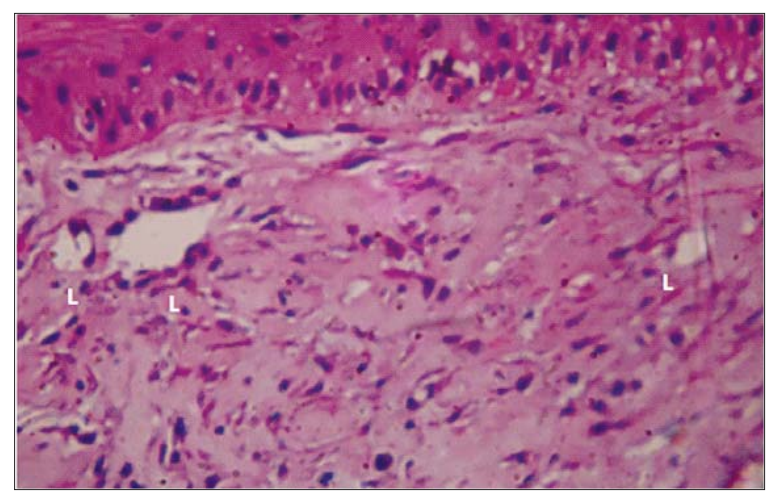

Figure 5. Lymphatic vessels (L) near myofibroblasts replacing Bowman's membrane in the cornea 